\title{
Borders and belonging: displaced Syrian youth navigating symbolic boundaries in Lebanon
}

\section{Citation}

Chopra, Vidur. No date. Borders and belonging: displaced Syrian youth navigating symbolic boundaries in Lebanon. Doctoral dissertation, Harvard University.

\section{Permanent link}

http://nrs.harvard.edu/urn-3:HUL.InstRepos:42659202

\section{Terms of Use}

This article was downloaded from Harvard University's DASH repository, and is made available under the terms and conditions applicable to Open Access Policy Articles, as set forth at http:// nrs.harvard.edu/urn-3:HUL.InstRepos:dash.current.terms-of-use\#OAP

\section{Share Your Story}

The Harvard community has made this article openly available.

Please share how this access benefits you. Submit a story.

\section{Accessibility}




\title{
Borders and Belonging: \\ Displaced Syrian youth navigating symbolic boundaries in Lebanon Short Title: Borders and Belonging
}

\author{
Vidur Chopra $^{1}$ and Sarah Dryden-Peterson ${ }^{2}$ \\ ${ }^{1}$ Teachers College, Columbia University \\ ${ }^{2}$ Harvard Graduate School of Education
}

\section{Author Biographies}

Vidur Chopra (vidur_chopra@mail.harvard.edu) is a postdoctoral research fellow at Teachers College, Columbia University. His research examines the ways education policies, programs and practices foster or hinder young people's belonging with their communities and nation-states, during and post-conflict.

Sarah Dryden-Peterson (sarah_dryden-peterson@gse.harvard.edu) is an Associate Professor of Education at the Harvard Graduate School of Education. Her research focuses on education in armed conflict and the ways in which learning, pedagogies, and relationships may alter trajectories of conflict for nation-states and individuals. She is recipient of the Palmer O. Johnson Award for outstanding article and a National Academy of Education Postdoctoral Fellow.

\section{Acknowledgements}

We express our thanks to all our research participants, to Dr. Fernando Reimers, Dr. Sara Lawrence-Lightfoot, and to colleagues at the Harvard Graduate School of Education's Mowana Lab for their feedback on the work.

\section{Research Ethics}

This research was reviewed and approved by the Committee on the Use of Human Subjects at Harvard University (IRB15-3706). All interview participants were aware of our roles as academic researchers and provided with an information sheet about the research, its potential risks and benefits, and their rights within the research; all gave their oral consent for participation. All appropriate steps were taken to protect participants' confidentiality.

\section{Funding}

This research was made possible with support from the Sinclair Kennedy Traveling Fellowship and the Dr. Stephan G. and Wanda W. Jones Scholarship Fund at Harvard University.

\section{Disclosure statement}

The authors hold no financial interest or known benefit that has arisen from the direct applications of this research. 


\title{
Borders and Belonging: Displaced Syrian youth navigating symbolic boundaries in Lebanon
}

\begin{abstract}
We examine the ways in which young Syrian refugees perceive and navigate the symbolic boundaries of belonging when displaced in Lebanon. Using portraiture, we identify three dimensions of belonging for refugees - safety, dignity, and relationships - and we explore the role of education in cultivating each one. We find that educational spaces, such as formal school and informal volunteering experiences, are places where refugee young people are at times able to blur bright boundaries of belonging. We also find that this belonging is tenuous and serves to reinforce boundaries of citizenship, rights, and everyday practices that exclude refugee young people. Our findings emphasize the need for the field of refugee education to address the question of how schools can actively resist and counter state-established bright boundaries of belonging to instead serve as spaces that blur and redefine those boundaries.
\end{abstract}

\section{Keywords}

Refugee education, belonging, citizenship, youth, portraiture, boundaries 


\section{Borders and Belonging: Syrian youth's experiences of displacement in Lebanon}

On 14 February 2015, 23-old Ali, a Syrian refugee in Lebanon, handed out roses to Lebanese passersby in Beirut's bustling Hamra district. Attached to each flower was a handwritten note: 'From the Syrians to the Lebanese people - thanks for hosting us, thanks for the hospitality.' Some citizens brushed away the group of young Syrians, overlooking them entirely. Others were suspicious and thought Ali was asking for money. A third group of Lebanese noted it was their 'duty' as Lebanese people to expand the boundaries of inclusion and belonging.

Refugees, like Ali, have crossed a border to flee persecution, war, or violence. As they cross territorial borders, they often confront other boundaries that host country governments and citizens construct. Nationality, citizenship, and the rights afforded to refugees are among the many ways in which these boundaries are marked. International global instruments, like the 1951 Convention Relating to the Status of Refugees, articulate refugee rights; yet, host countries must in turn interpret and apply them. Even when host countries create provisions for refugees to access social services, the everyday practices of host country citizens can create another set of boundaries, expanding or constricting refugees' sense of belonging. Like Ali's experience on Valentine's Day, refugees' relationships with host country citizens are variegated, with implications for their experiences of exile and belonging.

Existing global refugee policy envisages refugees' belonging and their long-term futures as inherently attached to, and bounded within, nation-states and their physical borders (United Nations 2018; Dryden-Peterson et al. 2019). However, socio-anthropological research on refugees' experiences in host countries decenters nation-state-based and legal categorizations of refugees in its illumination of multiple forms of refugee belonging that exist, despite, or in 
addition to, persistent legal- and policy-based tropes (Hovil 2016; Landau and Amit 2014; Kuch 2017). These works identify numerous ways in which refugees subvert formal conceptualizations of nationality and legal citizenship or the lack thereof, to locate less recognized belonging within sub-national, local communities. In Global North contexts, there is a growing body of literature on ways that education - both formal and non-formal - can be space for this renegotiation of belonging (Bajaj \& Bartlett, 2017; Koyama, 2019). Building on this work in a country of first asylum, we examine how young Syrian refugees perceive and navigate the boundaries of belonging when displaced in Lebanon, with a focus on education. In theorizing belonging, we use portraiture, a qualitative social science methodology, to identify three central dimensions of belonging for refugees - safety, dignity, and relationships - and we explore the role of education in cultivating each one. We find that in educational spaces, such as formal school and informal volunteering experiences, refugee young people are at times able to blur bright boundaries of belonging. We find that this belonging is nevertheless tenuous, also reinforcing boundaries of citizenship, rights, and everyday exclusionary practices, illuminating both challenges and opportunities for educational spaces as sites of both boundary maintenance and blurring.

\section{Refugee Belonging: Defining and Navigating Boundaries}

Belonging is often described as feeling a sense of 'home,' where home symbolizes familiarity, comfort, security, and attachment (Antonsich 2010; Yuval-Davis 2006). Antonsich (2010) highlights five factors that contribute to this sense of home: 1) auto-biographical factors related to past history or childhood memories; 2) relational factors or stable inter-personal, caring, and supportive relationships; 3) cultural practices, most significantly language, spoken and unspoken, that allow individuals to construct and communicate meaning, and feel heard and 
visible; 4) economic factors including stable material conditions that facilitate individuals' sense of stake in the place they live; and, 5) legal factors producing a sense of safety and resources, including rights, for managing uncertainty and risks when they emerge.

Forced displacement complicates refugees' sense of belonging. Conflict-induced displacement resulting from a state's use of force, or its inability to safeguard and uphold its citizens' rights, can be an experience of 'failed citizenship' (Banks 2017), rupturing refugees' sense of national belonging vis-à-vis their home country. In displacement, refugees leave home countries and established relationships. Forging new social relationships in countries of exile require bridging differences, in new languages, and according to unfamiliar 'rules of the game.' Urban refugees are often socially isolated, residentially segregated in poor neighborhoods; possess limited legal protections including rights to freedom of movement, work, and quality education; and often face xenophobia, forced evictions, and organized crime (Crisp, Morris, and Refstie 2012).

Though belonging, on the one hand, is an individual phenomenon experienced at a personal, inter-subjective level, it is equally about membership — to a group or collective (Skey 2013). Belonging becomes an inherently social endeavor, in relationship to the presence or absence of the other (Antonsich 2010). It thus involves acts of claiming one's membership within a collective, while simultaneously marking and securing the boundaries of that belonging, what (Yuval-Davis 2006) calls the 'politics of belonging' (p. 204). Belonging is therefore fundamentally about boundary creation and maintenance.

One boundary that circumscribes refugees' belonging, less in the Global North but almost universally in countries of first asylum, is lack of citizenship within the host country. As noncitizens, refugees are unable to draw on the legal frameworks and resources available to 
citizens (Dryden-Peterson 2016). In the absence of a citizenship-based anchor, refugees are often 'pushed into the gaps between states' (Haddad 2008, p. 7). In practice, this means that though global human rights-based norms shape refugees' aspirations for belonging in a host country, the policies and practices of host country governments eclipse and dash their hopes for belonging with local host country citizens (See Simonsen 2017,for a useful distinction of immigrants belonging in or belonging with the nation).

Refugees also encounter symbolic boundaries. Symbolic boundaries refer to 'conceptual distinctions made by social actors to categorize objects, peoples, practices, and even time and space' (Lamont and Molnár 2002, p. 168). Boundaries aid individuals' sense of self and group membership. Through its practices and inter-subjective schema, boundary-making guides interaction among individuals, generating distinctions, relegating individuals to belong to either side of the boundary. When the cultural repertoires and scripts underlying these boundaries are sufficiently internalized by a large group of people, they produce inequalities and exclusions, resulting in unequal access and distribution of material and nonmaterial resources. In this way, individuals within boundaries assert legitimacy and acquire resources, habits, or competences (Lamont 1992), thereby deepening inequalities and disrupting a sense of belonging for those outside the boundary.

The nature of these symbolic boundaries dictates how individuals manage, negotiate, or contest them. Bright boundaries, Alba (2005) argues, are those where individuals know at all times which side of the boundary they lie on, such as nationality and citizenship in the case of refugees. Blurred boundaries, on the other hand, allow individuals to manage and present their sense of self in complex and hyphenated ways, enabling them to occupy ambiguous locations with regards to the boundary. By obscuring 'insider-outsider' categories, blurred boundaries 
facilitate the development of belonging. Historical relations between home and host countries and social, cultural, and legal institutions in the host country determine whether refugees are able to blur boundaries. For example, when language, religion, and cultural traditions and practices are shared, as in the case of Syrian refugees in Lebanon, there are possibilities for refugees to blur boundaries. However, in times of mass migration and extensive histories of conflict, as also in the case of Syrian refugees in Lebanon, boundary shifting, or re-drawing of boundaries remains far more challenging (Alba 2005) because groups of citizens feel threatened by the presence of outsiders or noncitizens like refugees, and/or have sufficiently internalized prejudices against the other.

Education is a particularly relevant space in which young people confront and manage symbolic boundaries (Oikonomidoy 2009). The structures and substance of education shape how youth from minority groups, including refugees, perceive themselves as individuals and members of groups to manage the boundaries of belonging. In post-conflict Guatemala, Bellino (2017) finds teachers' decision-making about history teaching can either forge collective identity or justify discrimination and exclusion. Similarly, in Botswana, when school administrators and teachers deliberately do not make space for discussing experiences of inequality among ethnic groups, students from minority ethnic groups experienced boundaries on their belonging within the school's mono-cultural representations of unity over diversity (Mulimbi and Dryden-Peterson 2017). Everyday nationalism that can permeate American classroom practice and pedagogy constructs symbolic boundaries, situating Palestinian immigrant youth outside bright boundaries of national belonging and being American in a post-9/11 world (Abu El-Haj 2015; Sirin and Fine 2007). 
Boundary creation and blurring, for refugees, as noncitizens, is not contained within nation-state spaces (Hovil 2016; Van Hear 2014). Through their involvement in transnational affairs (Al-Ali, Black, and Koser 2001), protests and political campaigning (Clark-Kazak 2011), young refugees challenge dominant discourses that collapse belonging with legal citizenship and national membership. Through these acts of informal mobilization, refugees act as citizens, asserting their 'right to claim rights' (Isin 2009, p. 371). However, Bloemraad (2018) warns that though these informal acts of 'grassroots citizenship' (p. 13) enable minority groups to claim belonging, they remain structured by legal and institutional practices that exert power to maintain bright boundaries. Belonging can therefore not be a dichotomy distinguishing 'us' from 'them'. Instead, perceptions and evaluations of belonging are fundamentally relational- and recognitionbased claims. They are thus a matter of degree - individuals or groups can be closer or further away from embodying the characteristics that allow them to blur the boundaries of belonging and claim their legitimacy within society (Bloemraad 2018).

\section{Syrian Refugee Belonging: Defining and Navigating Boundaries in Lebanon}

Lebanon and Syria's histories are deeply intertwined. Both countries gained

independence from French control in 1946. During the Lebanese civil war in 1975, Syria sent its troops to strengthen the Lebanese army. Syria's intentions soon flipped as a consequence of regional geo-politics, and tensions between Lebanon, Syria, Israel, and Iran prolonged the war through 1990. Syria ultimately withdrew all its troops from Lebanon in 2005, and in 2008 the two countries resumed diplomatic relations (Seeberg 2013). Despite political tensions between the two countries, people-to-people contact between Syrians and Lebanese persisted. Many Lebanese sought refuge in Syria. Further, Lebanese and Syrian people were integrated in each 
other's social and economic lives through inter-marriages; a visa-free policy for citizens of the two countries; and, the presence of nearly half-million Syrian workers in Lebanon (Chatty 2017; Seeberg 2013).

By October 2016, the time of this research, the Government of Lebanon (GoL) estimated hosting 1.5 million refugees, the largest number of refugees per capita, globally (UNICEF, UNHCR, and WFP 2016). This has been associated with rent increases, depression of daily labor wage rates, strained delivery of public services and decline in Lebanon's GDP (Government of Lebanon and United Nations 2015, 2017; Migration Policy Centre 2014). The Syrian conflict is estimated to have cost Lebanon nearly USD 14.5 billion thus far (International Monetary Fund 2017), and the GoL has felt its hospitality strained (Geha and Talhouk 2018). Memory of the notso-distant civil war stoked apprehensions that the presence of refugees will disturb the country's delicate sectarian balance.

A factious past and current socio-economic pressures have created conditions for cementing bright boundaries, communicating that the spaces for Syrians to belong in Lebanon are far and few. In Lebanon, the mass migration of Syrians threatens the country's century-old, but delicate, sectarian power-sharing balance within its government, a fear based in Lebanon's history of long-standing conflict and civil wars. Politicians, powerful elites, sectarian leaders, and even ordinary citizens complicit in sectarian clientelism, have exerted influence on the Lebanese government to adopt more assertive policy positions in managing and communicating to Syrian refugees that belonging fully in Lebanon is never possible (Geha and Talhouk 2018). Boundaries of legality further circumscribe Syrians' lives in Lebanon. Lebanon does not recognize Syrians as refugees, instead labels them as 'displaced' and 'temporary guests' (Human Rights Watch 2016b; Chatty 2017). All Syrians over 15 must obtain a temporary visa, renewed 
annually for 200 dollars, to maintain legal residency (Janmyr 2016; Human Rights Watch 2016b). With more than 70 percent of displaced Syrians below the poverty line (Government of Lebanon and United Nations 2017), many are unregistered and classified as 'illegal'; in 2016, nearly two-thirds of Syrians in Lebanon lacked legal residency (Human Rights Watch 2016a). Without legal status, most young Syrians work in the informal labor market, subjected to less than minimum wages and little job security. At the time of this research, to enter university, Syrians needed to submit evidence of their high school leaving examinations, previously not accepted without simultaneous proof of legal residency.

Symbolic boundaries pervade young Syrians' daily lives, including virulent and vilifying social media campaigns; widespread discrimination; regular stop and frisk procedures at military checkpoints, particularly for young, Syrian males; and local-level vigilantes who restrict Syrians' freedom of movement (Chatty 2017). Collectively, these policies and practices shape the boundaries of belonging for young Syrians' in Lebanon.

\section{Methodology}

The data for this study draw from the principles of "portraiture," a social science methodology rooted in the phenomenological paradigm (Lawrence-Lightfoot and Davis 1997), that explores the "meaning of people's experiences in the context of their lives" (Seidman 2013, p. 20). We use portraiture as a methodological approach for two reasons. First, most portrayals of refugee youth are reductionist, driven by tropes of passive victims, or harbingers of violence (Clark-Kazak, 2011). In its search for "goodness," portraiture, moves away from these facile, pathologizing representations, acknowledging that individuals' strength and resilience are also accompanied with promise, vulnerability, and weakness. This pursuit of goodness does not 
disguise or deny weakness and negative experience. Second, portraiture allows us to capture the complexity of the human experience, in this case the sense of loss and liberation that accompanies young refugees' flight from armed conflict and a repressive political regime. In so doing, portraiture is able to attend to and integrate these paradoxes within the inquiry and narrative (Lawrence-Lightfoot and Davis 1997).

The three portraits presented here are drawn from a larger study undertaken in 2016, examining 15 young Syrians' experiences of displacement, higher education, and the social supports they marshal in charting their education and life pursuits (Chopra 2018). Our sample included 15 participants between the ages of 18-30 years; forcibly displaced by conflict in Syria; self-identified as living in Lebanon's capital, Beirut, or its surrounding Mount Lebanon area, since 2013; some basic English, the language of the interview; and, either currently enrolled in formal, certified higher education opportunities in Lebanon or having disrupted, temporarily or indefinitely, their higher education trajectories owing to conflict. In this study, we theorize belonging among refugee youth through three portraits of Azaa, Ali, and Amal. We do so because Azaa, Ali, and Amal illuminate patterns and leverage comparisons in the sample. The themes that echoed within these three portraits were resonant across the data: the vulnerability that accompanied their quests for visibility and recognition as individuals as they fled a brutish state, and the myriad ways in which they exemplified agency, despite the ongoing uncertainties confronting them as refugees. Each of these participants also allow us to illuminate variation in the sample, including in comfort levels in Lebanon, the time they had spent in the country, their education experiences, and their plans for the future.

Portraiture entails "a blending of qualitative methodologies—life history, naturalist inquiry, and most prominently, that of ethnographic methods" (Dixson, Thandeka and Djanna 
2005, p. 17). In our three-series interviews (Seidman 2013), we explored young Syrians' life histories, the ways they described and perceived symbolic boundaries in Lebanon, how these boundaries connected to their sense of belonging, and the repertoires they used to navigate these boundaries (Lamont and Molnár 2002). Each of the interviews lasted approximately 90 minutes. Interview data was complemented by participant observation in neighborhoods and places of work, where possible. For example, in Ali's case, Chopra accompanied him to his work, a video game parlor, and his volunteering site. Similarly, he spent time in Azaa and Amal's university, instances which provided context-specific details that further informed the interviews and data analysis.

Analysis of the interview data was on-going and iterative. Following each interview, we created notes from the audio recordings to organize participants' ideas into broad analytic categories and themes and to prepare for subsequent interviews. We subsequently transcribed all interviews and used Atlas.ti to formally code all data. Select examples of codes included: Relationships with Syrians and Lebanese; countering discrimination; educational experiences in Lebanon; activism and civic participation; and locating support. Further, we wrote a set of analytic memos to examine inter-relationships and patterns between different sets of data, specifically examining convergent or contrasting patterns. Our analysis focused not just on the everyday strategies that participants adopted when they encountered boundaries, but also the ways they, too, constructed or blurred boundaries of belonging for others. We present our findings in a series of three portraits focused on experiences and meaning-making, cornerstones of our phenomenological approach, the nuances of which are central to our theorizing of belonging for refugees. Our analysis finds three concepts central to refugee belonging, which these three portraits define and explore: safety, dignity, and relationships. 


\section{Findings: Syrian Refugees Navigate Belonging in Lebanon}

\section{Azaa: Belonging as Safety}

On Hamra Street, Beirut's erstwhile intellectual and tourist hub, the reverberations of the Syrian conflict are visible. Besides its exorbitant rent-paying occupants, it has a new set of occupants: young Syrian refugee children, often unaccompanied by adults, coaxing passersby to spend a few dollars on the goods they sell, bunches of red roses, figs stuffed with pistachios and walnuts, and shoe-shining services. Beyond prospects of commercial transactions, Hamra Street offers Syrian children the chance of visibility; Beirutis cannot turn their gaze away from a conflict that is a few hundred miles away. The January $6^{\text {th }} 2015$ edition of An-Nahar, Lebanon's most widely circulated and oldest Arabic daily newspaper, carried an article titled, 'Hamra [Street] is no longer Lebanese...Syrian expansion has altered its identity.' The article asserted that Syrians had no claim to Hamra Street.

Yet it is here we find 23-year old Azaa nestled under a pink umbrella inscribed with the Dunkin Donuts logo. Dressed in fitted crimson sweater and black tights, with a half-spent cigarette in her right hand, she is engrossed in a book. She explains that the book is a course text for her upcoming exams in social and economic development. In our last meeting, Azaa shared her anxiety about passing her university exams. In addition to being a full-time student at the Lebanese University, Lebanon's only public university, Azaa is also the sole breadwinner for her ailing parents who live with her in Lebanon. To fulfill these commitments, Azaa juggles multiple part-time jobs: sometimes as an Arabic-English translator, other times as a teaching assistant at an NGO-school for Syrian refugees. 
'My life sucks,' Azaa said the last time we met. 'I won't have [a] salary next month and I'm freaking out right now...I'm so worried about this year because Lebanese University is so hard and I don't have time to read books, or to learn more English, or to study.' As a young Syrian in Lebanon, Azaa's relationship with her university and consequently, with Lebanon, is complicated. After the fourth and final time she was tortured in a Syrian government prison, Azaa knew she could no longer be safe in Syria. Without letting her parents know, Azaa arranged for a taxi to take her to Lebanon, where her sister was living. En-route to the border, Syrian guards summoned Azaa: 'We're going to let you go, but never return again or we will kill you.' In the moment she crossed the Syrian-Lebanese border, her fear transformed. From one that crippled her, the fear now awakened and enlivened her. As she vividly describes the scene, Azaa exhales a loud sigh of relief, touches both her arms, and says aloud, 'I'm alive. I'm here. I'm alive!'

Azaa's unwavering commitments to free speech, peaceful protest, and human dignity even when risky - seem inscribed in her genes. In his heydays, Azaa's father protested against Hafez Al-Assad, Syria's current President Bashar Al-Assad's father. As a result, the family was forced to flee to Iraq, where Azaa was born, returning to Syria many years later. Her parents forewarned her of the many risks accompanying political activism in Syria, but Azaa, like her father, was not one to succumb easily. Willing to risk her life, time and again, she explained: 'Syria is my country...I'm a citizen, so it's my responsibility... if I feel like something is wrong, I should do something about it.'

Once in Lebanon, Azaa's mother sent her Syrian educational certificates through a taxi driver crossing the Syrian-Lebanese border so Azaa could resume her studies. But Azaa was not ready to resume her studies. Mentally and physically worn, Azaa touches her back and left knee, 
sounding out an entire color palette to describe her wounds and the pain she endured. 'My back was all green and yellow, uhh all green and blue because of the uh...' A deliberate silence lingers. Her words trail off, but from our previous conversations, that she is referring to her torture in prison is clear. In Syria, Azaa motivated herself to 'just keep going...to forget that anyone has hit you.' In Lebanon though, without a job or university, the incidents in prison played on loop in Azaa's mind. Unsure of where to seek help or whom to speak to, Azaa remembers spending her time 'reading and communicating with myself.' In her short lifetime, Azaa has experienced a multitude of extreme emotions. From the adrenalin rush accompanying protesting and of being on the precipices of democracy, to loneliness and depression in exile in Lebanon, Azaa acknowledges the onset of a new emotion: guilt. 'I know a lot of people are now outside Syria and they regret it and they feel guilty about it, and I'm one of them. I want them to know it was not really a simple experience to live.' Worn, but agentive, Azaa tried not being idle in Lebanon, volunteering her time with education NGOs supporting Syrian refugees in need, attempting to simultaneously tackle her guilt and find renewed purpose.

A year after she arrived in Lebanon, Azaa decided to resume university. Though her Lebanese peers paid US\$350 tuition, as a Syrian refugee, she paid twice that amount. At first, she learnt she would need to restart her university education. Embodying her name's meaning courage - Azaa refused to cave. She petitioned her case directly with the Ministry of Education. She describes walking into a bureaucrat's office, setting her bag on his table and waiting quietly in front of him for 50 minutes. When he finally took notice, she proclaimed, 'I' $m$ in the third year and you will put me in the third year and if you don't want to put me in the third year, I will stay in your office forever...I want to continue my education and whether you like it or not, I'm going to do it.' The bureaucrat eventually agreed, only after letting her know that she had a 
'mind of a rock.' Azaa finally enrolled in her third and final year at university, continuing from where she had left off in Syria. With a tone of levity, Azaa explicates the 'trick' for navigating these boundaries, hurdles few other Syrians like her have been able to leap over: 'The trick is to be serious with them, to be like I'm stronger than you and I'm going to have whatever I want from you - this is the trick!' In Azaa's eyes, there is no room for Syrians to display weakness within sight of the Lebanese public's gaze.

Once Azaa stepped inside the seemingly calm buildings of her university, her old and new worlds collided. On campus, Azaa found walls plastered with Hezbollah and Harakat Amal's posters, Lebanese political parties associated with Lebanon's Shia Muslim sect reported to hold close ties to Iran, and close allies of the current Syrian regime. Azaa's father's Lebanese friend, had cautioned her to stay silent of her involvement in the Syrian revolution. For a month, Azaa remembers sitting alone in her cafeteria, surrounded by Lebanese peers who followed conservative parties and spoke ill of Syrian refugees. She heard them sneer: 'We don't want Syrian refugees in Lebanon. They are destroying our country...We are with the Syrian regime and we think the revolution is wrong.' Fellow Lebanese students often asked Azaa her full name to speculate about her religious sect and political allegiances. Azaa knew that the only way to gain belonging at university was to 'change the story.' From privately being vehemently against the Syrian regime, Azaa became publicly an ardent follower of it.

Azaa soon realized that the physical and psychological safety that undergirded her sense of belonging at the Lebanese university was fragile. Though physically safe from torture, she protected herself psychologically by pretending to be someone she was not. This tenuous psychological safety was shaken when she came face-to-face with one of her Syrian captors on campus, 'the scariest day of my life.' In her university in Syria, Azaa had once been caught by 
the mukhabarat for fanning her political views in the open. This same captor had links with a political party's student club in the Lebanese University and was by chance visiting, when he recognized Azaa. He approached her while she was with her new, Lebanese friends. With an air of coolness, Azaa brushed him off: 'I'm sorry I can't remember you. I know many people so I can't remember everyone in my life.' He continued persisting, providing more details about their encounter than she wanted her Lebanese peers to know. Azaa inhales deeply and holds her breath to mimic the only thought pre-occupying her in that instance, ' $\mathrm{F} \%$ *\#, I'm done today, right now!' Azaa took her captor aside, once again sewing a different narrative of her allegiances: 'I see the importance of the Syrian regime and I'm with you guys...I don't want the Syrian revolution again.'

When Azaa draws an identity map, a pictorial representation of her identity and story, she sketches a large set of eyes in saffron. The eyes are wide, awake and alert, seemingly peering over an imaginary object. Below the pair of eyes, she writes: 'I feel there is someone watching me all the time.' The unsettling feeling of hyper-vigilance has led Azaa to feel she is 'back in Syria again.' Once free from the manacles of a dictatorial regime, Azaa finds herself trapped in Lebanon. She takes out her lighter for yet another cigarette, and remarks, 'Until now I can't say my opinions about the Syrian regime and there's a lot of people talking about the Syrian regime, about the Free Syrian Army, and about the revolution. I feel like I'm stuck in Syria all over again.' Though away from the Syrian regime, Azaa's safety remains undermined at university. The political repression that impelled her to seek refuge in Lebanon has transformed in appearance, but hovers in essence. Repression now comes from the opinions of ordinary Lebanese citizens, 20-something-year olds, still coming to terms with who they are. Azaa knows that to confront these deeply entrenched, sectarian-based symbolic boundaries in Lebanon, she 
must create herself multiply. She deliberately creates an entirely different version of herself and her past, one where she sides with the aggressors, in order to protect herself. For Azaa, belonging, without first establishing safety, is elusive.

\section{Ali: Belonging as Dignity}

The first time we meet, Ali, age 23, saunters into a café in all black ensemble: skinny black jeans accentuating his slender frame, a black sweatshirt, and a string of black beads dangling from his left wrist. Ninety-nine in number, the beads are used by some to count and recite the names of the Allah; others, like Ali, use them as worry beads. Ali's timbre is soft and unenthused, his characteristic bun is untidily held up, and his eye sockets are hollow and enveloped in dark circles marking fatigue and exhaustion. 'I was kicked out from my house yesterday,' he says, ten minutes into our conversation. 'The owner had a better offer. We used to pay rent for 650 [dollars]. Someone came to her and paid 750.' Ali and his three other Syrian flatmates were given four hours to evict the premises. Ali attributes the incident to him being Syrian, to having 'no established rights' as a noncitizen in Lebanon. Frustrated, he contrasts his liminal legal status to that of the Lebanese: 'The Lebanese people ... have someone to help them in the security system, in the military. Anyone can help them. I have nobody.' Ali remains acutely aware that his Syrian nationality limits his ability to cross boundaries and to make claims on his rights in Lebanon.

When Ali describes the word home, he looks away and murmurs, 'safety,' echoing Azaa, and then emphatically adds, 'Home is the place where I work and live with dignity.' As he reminisces his home in Aleppo, his description is universal and familiar, imbued with the warmth and affection of loved ones; the fragrance of morning jasmine, freshly baked bread and the brew 
of Arabic coffee trailing his neighborhood streets; and, the melodious strains of Fairuz, a worldrenowned Lebanese singer titled as an 'Ambassador to the Stars.' Many of these characterizations cut across borders and are present in Lebanon too, including Ali's family. But in Ali's eyes: 'Lebanon doesn't belong to me.'

Belonging to a nation-state, for Ali, is murky and far from being a facile binary. Though Lebanon does not belong to Ali, no longer did Syria belong to him either. As a young male, Ali was desperately trying to escape a year and a half's worth of military conscription. Twice, Ali used his university enrollment to delay his military conscription. The third time, the officer asked for a hefty bribe that Ali refused to pay. Ali recalls the experience as inherently 'humiliating,' one for which he was imprisoned for eight days. Ali knew that Syria was becoming a country where his dignity would continue being infringed upon.

Though the southern Turkish border is barely 90 minutes from Aleppo, Ali and his family decided to come to Lebanon instead, in the fall of 2012. He rationalizes the decision: 'I was hoping to continue my study in Arabic...We came here because here there is Arabic language and we can easily connect with the people.' Little did Ali know that 'connection' with Lebanese would remain eclipsed by episodic incidents of discrimination and xenophobia. For three years, Ali lived and worked in Beirut's Shatila camp, home to nearly 22,000 Palestinians who sought refuge in Beirut in 1949. With newly arrived refugees from Syria, Shatila's population increased to nearly 40,000. The physical presence of Shatila and other Palestinian refugee camps in Lebanon serve as a continual reminder, to the Lebanese government and Syrian refugees, of how long-enduring conflict can unendingly leave displaced individuals in limbo, complicating their sense of belonging. 
To familiarize himself with Lebanon, Ali volunteered with different NGOs in Shatila, where he received a subsistence allowance. Ali describes 2013 and 2014 as a time where he 'forgot about studying,' one where he was 'only thinking about how to live the next day.' Volunteering was transformative for it renewed his belief in humanity: 'When you help someone, you feel that when you need help, someone will help you.' Ali's volunteering with organizations predominantly serving refugees was a way to 'help [his] country [Syria] citizens: a country of refugees.'

At our next conversation, on a foldable table in a low-ceilinged parking lot, Ali and four other Syrian volunteers have placed crayons, red plastic string, a few finger puppets, glue sticks, and a bottle of hand sanitizer. The volunteers have white apron-like vests, clumsily knotted across their shoulders, a uniform to signal their role to Hamra street's children who Ali has gone to round up. With pride he beams, 'I know them all.' Five children walk in and are enthusiastically cheered on by the volunteers. One leads with stretching exercises and call and response rhymes in Arabic. Ali walks in with four other children, much tinier than the previous ones. The group expands to form a circle, and the younger children are enraptured by a talking puppet, while the older children watch and listen patiently, but doubtfully. In this moment, these children can escape the constant snubbing of pedestrians and adult responsibilities that dominate their lives, reclaiming traces of childhood otherwise ruptured by forced displacement. The activities are short and transition quickly to drawing, followed by sugary drinks and fried snacks. To mark the event's end, the volunteers encircle the children and break into the Chicken Dance, gently goading them to join. For a moment, Ali, too, becomes a child, lost amidst infectious giggles and delight. Ali's act of eliciting joy from the group is also an act of service, as he upholds the dignity of Hamra Street's otherwise overlooked Syrian children, and of himself. 
Unable to openly voice his political views in Syria for fears of imprisonment, Ali recalls claiming his visibility in Lebanon through relationships fostered in his volunteering and more publicly in non-violent demonstrations. With other Syrians, Ali protested several incidents that served as touchstones in Syrians' experiences in Lebanon: Russia's support of the Syrian regime; Lebanon officially closing its borders to Syrians, mandating all Syrians to register themselves annually. Despite Ali's many protests, deep down, he knows that 'nothing is going to happen like we [Syrians] want.' Yet, these non-violent protests have enabled him to assert his voice with dignity, to make his presence as a Syrian felt: 'It is just to say that there are Syrian people, there is a Syrian voice here in Lebanon.'

At the same time, Lebanese people have contested these protests with discriminatory slurs, contesting his and other Syrians' claims to belong in Lebanon. Ali recounts when a taxi driver slowed his car to shout over the protestors: 'Go away, go home! You destroyed your Syria, your country. You did a lot in Syria. Don't do this here!' Ali's strategy is to wait and silently observe from a distance: 'You can't say anything to him because he's Lebanese and you're Syrian.'

Ali remains conscious of the limited support to Syrians to live with dignity in Lebanon. While his Syrian friends have undertaken perilous journeys across the Mediterranean, Ali refuses to live as an 'illegal' or 'irregular' migrant in a detention center in Europe: 'I was waiting for the real chance. I don't want to go by sea.' Ali knows that being a refugee in Europe will entail navigating yet a different set of symbolic boundaries, one that he is unwilling to cross.

After several futile attempts to leave Lebanon legally, Ali was finally awarded an education scholarship in Latin America. With a pathway to legality and education in sight, and to avoid incurring university tuition costs, Ali dropped out of university in Lebanon. But as the 
summer came and went, Ali was yet to receive the funds to leave. His sponsors - university students — told him that they were still fundraising and needed additional time. For a year, Ali placed his education on hold.

When the exit from Lebanon was imminent, a large group of Ali’s Syrian friends organized a farewell. Surrounded by them, Ali's face glows in the soft light of a Beiruti dusk. Ali's strategy to navigate Lebanon's symbolic boundaries was one of deliberate waits: to wait patiently for the scholarship to arrive while others imperiled themselves; to wait and refrain from reacting when incited with xenophobic slurs; and to wait to not just belong and embrace any country, but instead for the country to belong and embrace him. He hopes his new journey will not just take him further away from a home already left behind, but closer to finding a home where he can 'work and live, with dignity.'

\section{Amal: Belonging as Relationships}

To see the sky, one must peer through the web of Bourj Hamoud's flimsy, interlaced electric wires precariously connected to the neighborhood's street lamps. Though a majority Lebanese-Armenian neighborhood, Bourj Hamoud is also home to Lebanese Christians, Shi'a Muslims, Kurds, Palestinians, Iraqi Christians, and a growing mix of migrant labor from Bangladesh, Ethiopia, Philippines and Sri Lanka.

For 18-year old Amal, home is not here, it is Syria: 'My home represents my country...It's the place that I belong to. You feel comfortable, that you are surrounded by people like you...in principles, in tradition. There is no difference between you and them.' With little prodding, Amal transitions to narrating her schooling experiences in Syria. In Grade 9, missiles hit Amal's school playground, while she and her friends were in class. She folds her arms, 
crouching her head into a brace position to underscore what comes next: 'Just imagine, I spent three hours at school on the ground. Like this.'

Over an entire school year, Amal attended school intermittently, barely totaling a month. Though her descriptions of a school filled with children being bombed paint a picture of conflict that is grotesque and inhumane, her actions demonstrate unbridled agency. In the remaining months, to teach herself, Amal directly copied pieces of text from her Science textbook to cram and memorize curricula untaught at school but that she expected to appear on her Grade 9 examinations, the gatekeeper for senior secondary school. Threading the past with the present, Amal acknowledges the bearings of this strategy on learning advanced Science at university: 'My basics are very bad because I didn't understand. I just memorized everything.'

Arriving in Lebanon in 2012, Amal found a generous Lebanese school Director who made an exception by swiftly enrolling her in his public senior secondary school without waiting for her equivalency certificates. On her first day of school, her class was rehearsing a skit for the upcoming Lebanese Independence Day. The history, the rituals, and the language were unfamiliar. 'I didn't understand ANYTHING!' Amal shares emphatically, noting how 'hard and sad' she felt. Yet, Amal recalls participating in the rehearsals. A seemingly guileless act, it was replete with symbolism. As a then14-year old, participating was a strategy to mark her visibility in that moment.

From an all-girls school in Syria, to now being the only Syrian in a co-ed high school in Lebanon, necessitated Amal traversing a new set of boundaries. She describes the Lebanese as 'another community.' She notes, 'There are a lot of differences between our community and their community. It's okay to have problems at the beginning, but after that I got friends and we are like family.' The linearity of Amal's narrative is striking experiencing trials and tribulations at 
first, and then, finding friendship. Her rendition of the experience is seemingly devoid of the hues of substance and struggle, of the brightly etched barriers to belonging that she perceived in those first moments.

In those early days, Amal's relationships with her teachers were diverse. Amal recalls her English teacher, Michelle, as one who 'hated the person that is weak in [English] language.' Michelle, helped Amal leap across her language barriers, boundaries that for so many other Syrian learners were bright and impenetrable. Though she taught Amal just for a year, Michelle assigned Amal extra reading, including Edgar Allan Poe's poems, calling her to summarize in front of the class. Afraid of floundering, Amal tried refusing: 'No, no way, I can't.' But Michelle was not going to bow out to a hesitant student. 'No, you can! You can!' she coaxed her. Michelle further promulgated class norms that eased the social anxiety Amal experienced. She told her class: 'If anyone here laughs on her language or anything, I will decrease five points from your exam.' When Amal talks of her teachers, her tone comes off as increasingly articulate, steady, and confident: 'She [Michelle] motivated me that I can do it!'

Like Michelle, other teachers also adopted practices that enabled Amal to flourish and deepen her sense of belonging with school. In her first year, Amal's Chemistry and Mathematics teachers made concessions for her homework: 'If you know it, write it in Arabic [and] I will correct it.' Even though Amal had the flexibility of submitting her homework in Arabic, she did not avail the opportunity for it would not serve her learning goals in the long-run. Amal's Mathematics teacher explained concepts in Arabic and would turn to her at the end of the class: 'Amal, do you have any questions? Can I help you with something?'

Learning English not only facilitated subject-level comprehension, it also allowed Amal to foster friendships at school. Amal's tone is upbeat as she describes her 'whole class as a 
family.' She notes the fluidity of the boundaries of her friendships with those at school: 'We [used to] meet outside the school, going in trips together and do some activities together at school. When someone faced problems, we used to help them and we had many things in common.' From 'not knowing how to deal with people' to finding commonality with her Lebanese peers, Amal's relationships paved a way to foster belonging.

At public university though, the belonging that her relationships at school helped sow soon eroded. As the only Syrian Muslim in her class of 80 in the first year, Amal felt overexposed and undermined. The gaze of her classmates was penetrating, their jibes pernicious. ‘They didn’t respect my principles. They said very bad words. And I decided to never gain friends [at university].' These relationships were now marked by 'formality.' Amal 'feel[s] more relaxed' in the library, 'read[ing] a book instead of going with them [Lebanese peers].' Amal harkens back to the idea of principles, an idea that seems so central to her experiences of belonging: 'Your principle is more important than anyone. It's more important than making friends. When someone wants to be your friend, he will accept you in all your principles.'

When Amal began university, as a consequence of her past self-study and memorization strategies, her basics in Science were shaky. Unlike the relationships with teachers at her high school, Amal found a paucity of similar relationships at university. Amal's tone shifts to one of self-inflicted shame and guilt: 'All the Professors told me that your brain is not scientific... What are you doing here in Science?' Additionally, her classmates chastised her for wearing hijab. In their eyes, being a faith-abiding, pious Muslim was fundamentally incongruous with being a successful scientist. Amal describes her first year at university as one marked with depression, sadness, and tears. Though there was one professor who encouraged her to pursue her dreams 
'even though' she wore hijab, Amal's connections with her Lebanese university peers were tenuous.

As Amal experienced her sense of belonging rapidly evaporating, she established her own set of boundaries, marking what it means to belong to Syria and to be Syrian in Lebanon. Reflecting on Syrians who 'change their principles to gain friends,' Amal believes that 'most people will truly accept you because you really are Syrian and you conserve your principles.' Demonstrating a maturity uncharacteristic of an 18-year old, Amal reflects on all she has learned through her experience of forced displacement: of working hard and building character; of being exposed to an education system in Lebanon that values 'thinking logically' over rote; of gaining fluency and confidence in English. Referencing these benefits, she wants her Syrian peers to know that these benefits are not inherently incompatible with Syrian values, and that the twain can co-exist, through relationships, as they have in her case: 'You can adapt to Lebanese traditions, but without leaving your principles.'

\section{Discussion}

The experiences of Azaa, Ali, and Amal, point to three particular ways in which they, and other participants, construct and experience belonging as refugees in Lebanon. They have constructed belonging as marked by the presence of safety, dignity, and relationships, elusive though all three may be in different spaces and across time. Our work contributes to literature on where refugees find spaces of belonging, with implications for where and how refugee belonging could be fostered (Dryden-Peterson, 2016; Hovil, 2016). We focus specifically on implications for refugee young people and refugee education.

Through Azaa, Ali, and Amal, we see how conflict fractures and complicates young people's relationships with their home nation-state. Fears of persecution and threats to Azaa and 
Ali's freedom of speech and political beliefs damage their constructions of safety and dignity. Though Azaa, Ali, and Amal hold Syrian citizenship, their trust and belief in Syrian institutions is eroded. Their narratives are testimony to experiences of 'failed citizenship' (Banks, 2017), with resulting tenuous and ambivalent attachments to Syria.

Lebanon provides Azaa, Ali, and Amal a physical place to be in a critical moment of fracture with their home nation-state. Refugee rights enshrined in international conventions create among refugee youth, including our participants, expectations for the possibility of belonging in a host nation-state of exile. Azaa, Ali, and Amal find ways to live in Lebanon but, over time, they realize can never belong with Lebanon. Restrictions on freedom of movement, work, and education create bright boundaries of exclusion. Daily experiences maintain these boundaries, as Azaa, Ali, and Amal struggle to find dignity, work, pursue their education, and encounter physical and psychological risks of sharing their identities and political views. Over time, they begin to understand the tenuous nature of their belonging and how to navigate it. They feel forced to shift or hide their identities and build relationships that publicly buy into the status quo of bright boundaries that allow no space for them to 'claim legitimacy' (Bloemraad 2018) as Syrians in Lebanon.

Primarily through these experiences of bright boundaries that exclude, but also through small moments of blurred boundaries of belonging, Syrian young people in our study define an aspirational sense of belonging, rooted in safety, dignity, and relationships, helping us to understand the contours of belonging for refugee youth. Our participants' sought ways to cross boundaries, particularly in educational spaces. Azaa changed her identity narrative altogether, claiming different political allegiances so she could find enough safety at university without incessant questioning of her Lebanese classmates. 
In high school, Amal blurred the boundaries of belonging as the only Syrian student through relationships with a Director who made her feel visible and teachers who motivated and taught her English so she could participate not only in class but also in social interactions. One teacher explicitly blurred boundaries, refusing to let discriminatory laughter about language skills define Amal's experience in the classroom. At university, however, Amal did not find allies who could help blur these relational boundaries. In this context, the relational sense of belonging she had cultivated in high school became inwardly-focused, a dedication to preserving her own individual principles in the face of bright boundaries that excluded those principles from the collective space of the university. She was able to pursue an individual sense of belonging but not as a social endeavor toward membership (Antonsich 2010).

Azaa and Ali also sought to build relationships as pathways to belonging, but they found these relationships outside of school through volunteering. Azaa used volunteering as a way to take her mind off the psychological duress of her past and to search for meaning in the present. For Ali, volunteering was a way to preserve his dignity, in a space where he could be himself rather than pass as what he was not, and to create similar spaces of belonging for Syria's next generation. Not able to find spaces of belonging with Lebanese institutions, they found spaces for safety, dignity, and relationships with Syrian organizations. Yet while they blurred boundaries of belonging within these dedicated Syrian spaces, bright boundaries of exclusion defined their other experiences when interacting with Lebanese citizens and Lebanese institutions.

Azaa, Amal, and Ali's portraits point to the many ways in which they aspired for their education to help confront and navigate the ways in which Lebanese citizens and institutions drew bright boundaries. Yet the ways in which they continued to smack up against bright 
boundaries that excluded them from experiencing safety, dignity, and relationships - the components of belonging - point to the ways in which formal education, despite its aspirations, often fails to address society's most pressing social problems (Labaree 2012). The tensions between schooling's social aims and the politics underlying education reform are particularly evident in situations of forced migration. While educational institutions may aspire to be inclusive and welcoming spaces for all, these aspirations are often caught in the dilemma of limited resources and the consequent decisions on how much hospitality should be extended to noncitizens through formal public institutions, like schools, mandated to serve its citizens.

Importantly, while Azaa, Ali, and Amal find ways through formal and informal learning opportunities to navigate the symbolic boundaries of belonging that shape possibilities for safety, dignity, and relationships, their overarching experiences in Lebanon illuminate the fleeting nature of belonging in the face of bright boundaries. While Amal is able to blur the bright boundaries that shape Syrians' experiences of belonging in Lebanese society in her high school, the diffused nature of instruction and relationships in university preclude her from navigating boundaries in this same way. Moreover, at the same time as the host nation-state expands spaces of inclusion, such as access to schools, it also imposes exclusions such as on work or legal status, shrinking spaces for belonging outside of schools (Gonzales and Sigona 2017). Our findings contribute to emerging literature that emphasizes (See Dvir, Morris, and Yemini 2019) the need for the field of refugee education to address the question of how schools as sites of learning can actively resist and counter state-established bright boundaries of belonging to instead serve as spaces that blur and redefine those boundaries. It also points to the need for further research that examines ways that informal learning, outside of public institutions, such as volunteering through civil society initiatives, can afford opportunities to develop the 'navigational capacities' 
(Dryden-Peterson, Dahya, and Adelman 2017) to negotiate and blur boundaries of belonging and how transferable these skills might be to formal educational spaces, especially when these skills are not explicitly taught.

\section{References}

Abu El-Haj, Thea Renda. 2015. Unsettled belonging : educating Palestinian American youth after 9/11. Chicago ; London: University of Chicago Press.

Al-Ali, Nadje, Richard Black, and Khalid Koser. 2001. "Refugees and transnationalism: The experience of Bosnians and Eritreans in Europe." Journal of Ethnic and Migration Studies 27 (4):615-34. doi: 10.1080/13691830120090412.

Alba, Richard. 2005. "Bright vs. blurred boundaries: Second-generation assimilation and exclusion in France, Germany, and the United States." Ethnic and Racial Studies 28 (1):20-49. doi: 10.1080/0141987042000280003.

Antonsich, Marco. 2010. "Searching for Belonging - An Analytical Framework." Geography Compass 4 (6):644-59. doi: 10.1111/j.1749-8198.2009.00317.x.

Bajaj, Monisha, and Lesley Bartlett. 2017. "Critical Transnational Curriculum for Immigrant and Refugee Students." Curriculum Inquiry 47, no. 1): 25-35.

Banks, James A. 2017. "Failed Citizenship and Transformative Civic Education." Educational Researcher 46 (7):366-77.

Bellino, Michelle J. 2017. Youth in postwar Guatemala : education and civic identity in transition, Rutgers series in childhood studies. New Brunswick, NJ: Rutgers University Press.

Bloemraad, Irene. 2018. "Theorising the power of citizenship as claims-making." Journal of Ethnic and Migration Studies 44 (1):4-26. doi: 10.1080/1369183X.2018.1396108.

Chatty, Dawn. 2017. "How Syria's neighbors have treated its refugees." Current History 116 (794):337-41.

Chopra, Vidur. 2018. "Learning to Belong, Belonging to Learn: Syrian refugee youths' pursuits of education, membership and stability in Lebanon." EdD dissertation, Harvard University.

Clark-Kazak, C. R. 2011. Recounting Migration: Political Narratives of Congolese Young People in Uganda. Montreal: McGill-Queen's University Press.

Crisp, Jeff, Tim Morris, and Hilde Refstie. 2012. "Displacement in urban areas: new challenges, new partnerships." Disasters 36:S23-S42. doi: 10.1111/j.1467-7717.2012.01284.x.

Dixson, Adrienne D., Thandeka K. Chapman, and Djanna A. Hill. "Research as an aesthetic process: Extending the portraiture methodology." Qualitative inquiry 11, no. 1 (2005): 16-26.

Dryden-Peterson, Sarah. 2016. "Refugee Education: The Crossroads of Globalization.". Educational Researcher 45 (9):473-82. 
Dryden-Peterson, Sarah, Elizabeth Adelman, Michelle Bellino, and Vidur Chopra. 2019. "The Purposes of Refugee Education: Policy and Practice of Including Refugees in National Education Systems." Sociology of Education.

Dryden-Peterson, Sarah, Negin Dahya, and Elizabeth Adelman. 2017. "Pathways to educational success among refugees: Connecting locally and globally situated resources." American Educational Research Journal 54(6): 1011-1047.

Dvir, Yuval, Paul Morris, and Miri Yemini. 2019. "What kind of citizenship for whom? The 'refugee crisis' and the European Union's conceptions of citizenship." Globalisation, Societies and Education 17 (2):208-19. doi: 10.1080/14767724.2018.1525284.

Geha, Carmen, and Joumana Talhouk. 2018. "From Recipients of Aid to Shapers of Policies: Conceptualizing Government-United Nations Relations during the Syrian Refugee Crisis in Lebanon." Journal of Refugee Studies:fey052-fey. doi: 10.1093/jrs/fey052.

Gonzales, R. G., and N. Sigona. 2017. "Mapping the soft borders of citizenship: An introduction." In Within and beyond citizenship: Borders, membership, and belonging edited by R. G. Gonzales and N. Sigona, 1-17. New York: Routledge.

Government of Lebanon and United Nations. 2015. "Lebanon Crisis Response Plan: July 2015." UNHCR, Accessed 23 September. http://reliefweb.int/report/lebanon/lebanon-crisisresponse-plan-monthly-dashboard-inter-agency-coordination-lebanon-july.

. 2017. "Lebanon crisis response plan 2017-2020." In. Beirut.

Haddad, E. . 2008. The refugee in international society: Between sovereigns Cambridge, United Kingdom: Cambridge University Press

Hovil, Lucy. 2016. Refugees, conflict and the search for belonging Palgrave Macmillan.

Human Rights Watch. 2016a. "'Growing up without an education": Barriers to education for Syrian refugee children in Lebanon." In. Beirut, Lebanon.

—. 2016b. ""I just wanted to be treated like a person."." In. Beirut, Lebanon.

International Monetary Fund. 2017. "IMF: Lebanon selected issues " International Monetary Fund Accessed August 31.

https://www.imf.org/en/Publications/CR/Issues/2017/01/24/Lebanon-Selected-Issues44573.

Isin, Engin F. 2009. "Citizenship in flux: The figure of the activist citizen." Subjectivity 29 (1):367-88. doi: 10.1057/sub.2009.25.

Janmyr, Maja. 2016. "Precarity in Exile: The Legal Status of Syrian Refugees in Lebanon.". Refugee Survey Quarterly 35 (4):58-78.

Koyama, Jill. "Maps, Flyers, and Notebooks: The Materiality of Experts and Novices in Refugee Education." In Contested Spaces of Teaching and Learning : Practitioner Ethnographies of Adult Education in the United States, edited by Janise Hurtig and Carolyn Chernoff, 926. Lanham, Maryland: Lexington Books, 2019.

Kuch, Amelia. 2017. "Naturalization of Burundian Refugees in Tanzania: The Debates on Local Integration and the Meaning of Citizenship Revisited." Journal of Refugee Studies 30 (3):468-87. doi: 10.1093/jrs/few024.

Labaree, David F. "School syndrome: Understanding the USA's magical belief that schooling can somehow improve society, promote access, and preserve advantage." Journal of Curriculum Studies 44, no. 2 (2012): 143-163.

Lamont, M. 1992. Money, morals, and manners. Chicago: University of Chicago Press

Lamont, M, and V Molnár. 2002. "The Study of Boundaries in the Social Sciences." Annual Review of Sociology 28 (1):167-95. doi: 10.1146/annurev.soc.28.110601.141107. 
Landau, Loren B., and Roni Amit. 2014. "Wither Policy? Southern African Perspectives on Understanding Law, 'Refugee' Policy and Protection." Journal of Refugee Studies 27 (4):534-52. doi: 10.1093/jrs/feu005.

Lawrence-Lightfoot, Sara, and Jessica Hoffmann Davis. 1997. The Art and Science of Portraiture. San Francisco: Jossey-Bass.

Migration Policy Centre. "One million Syrians in Lebanon: A milestone quickly passed." European University Institute Accessed 03. http://cadmus.eui.eu//handle/1814/31696.

Mulimbi, Bethany, and Sarah Dryden-Peterson. 2017. "Responses to cultural diversity in Botswana's schools: links between national policy, school actions and students' civic equality." Journal of Curriculum Studies:1-23. doi: 10.1080/00220272.2017.1398353.

Oikonomidoy, Eleni. 2009. "The multilayered character of newcomers' academic identities: Somali female high-school students in a US school." Globalisation, Societies and Education 7 (1):23-39. doi: 10.1080/14767720802677358.

Seeberg, P. 2013. "Migration into and from Syria and Nontraditional Security Issues in the MENA Region: Transnational integration, security, and national interests." In Migration, security, and citizenship in the Middle East, edited by P. Seeberg and Z. Eyadat. New York, USA: Palgrave Macmillan.

Seidman, I. (2013). Interviewing as qualitative research. New York, USA: Teachers College Press

Simonsen, Kristina Bakkær. 2017. "What It Means to (Not) Belong: A Case Study of How Boundary Perceptions Affect Second-Generation Immigrants' Attachments to the Nation." Sociological Forum:n/a-n/a. doi: 10.1111/socf.12402.

Sirin, S., and M. Fine. 2007. "Hyphenated Selves: Muslim American Youth Negotiating Identities on the Fault Lines of Global Conflict." Applied Developmental Science 11 (3):151-63. doi: 10.1080/10888690701454658.

Skey, Michael. 2013. "Why do nations matter? The struggle for belonging and security in an uncertain world." The British Journal of Sociology 64 (1):81-98. doi: 10.1111/14684446.12007.

UNICEF, UNHCR, and WFP. 2016. "Vulnerability assessment of Syrian refugees in Lebanon 2016." In. Beirut, Lebanon

United Nations. 2018. "The global compact on refugees." In. New York: United Nations.

Van Hear, Nicholas. 2014. "Refugees, Diasporas, and Transnationalism." In The Oxford Handbook of Refugee and Forced Migration Studies, edited by Elena Fiddian-Qasmiyeh, Gil Loescher, Katy Long and Nando Sigona, 176-88. Oxford, U.K.: Oxford University Press.

Yuval-Davis, Nira. 2006. "Belonging and the politics of belonging." Patterns of Prejudice 40 (3):197-214. doi: 10.1080/00313220600769331. 